\title{
Quality of life domains affected in women with breast cancer
}

\author{
Os domínios afetados na qualidade de vida de mulheres com neoplasia mamária \\ Los dominios afectados en la calidad de vida de mujeres con neoplasia mamaria
}

GE Revista Gaúcha

de Enfermagem

\author{
Sabrina Nunes Garcia ${ }^{a}$ \\ Michele Jacowski ${ }^{b}$ \\ Gisele Cordeiro Castroc \\ Carila Galdino $^{d}$ \\ Paulo Ricardo Bittencourt Guimarães ${ }^{e}$ \\ Luciana Puchalski Kalinke ${ }^{f}$
}

DOl: $\quad$ http://dx.doi.org/10.1590/1983-

1447.2015.02.45718

\footnotetext{
Nurse, Master degree in Nursing, Institute of Oncology of Paraná, Member of the Grupo de Estudos Multiprofissional em Saúde do Adulto (Group of Multidisciplinary Studies in Adult Health) - GEMSA, Curitiba - Paraná, Brazil.

${ }^{b}$ Nurse, Specializing in Family Health at the Multidisciplinary Residency Program of UFPR, Member of the Research Group GEMSA, Curitiba - Paraná, Brazil.

c Nurse at the Hematology and Oncology Unit of Hospital Nossa Senhora das Graças, Member of the Research Group GEMSA, Curitiba - Paraná, Brazil.

d Nurse, Specializing in Oncology Nursing at Integrated Multidisciplinary Residency Program in Oncology of Hospital Erasto Gaertner, Member of the Research Group GEMSA, Curitiba - Paraná, Brazil.

e Statistician, PhD in Statistics, Associate Professor at the Department of Statistics of UFPR, Curitiba - Paraná, Brazil.

if Nurse, PhD in Sciences, Professor at the Postgraduate Program in Nursing at Universidade Federal do Paraná, Member of the Research Group GEMSA, Curitiba - Paraná, Brazil.
}

\section{ABSTRACT}

Objective: This study aimed to investigate the quality of life of women suffering from breast cancer undergoing chemotherapy in public and private health care systems.

Method: It is an observational, prospective study with 64 women suffering from breast cancer. Data was collected with two instruments: Quality of Life Questionnaire C30 and Breast Cancer Module BR23. By applying Mann Whitney and Friedman's statistical tests, $p$ values $<0.05$ were considered statistically significant.

Results: The significant results in public health care systems were: physical functions, pain symptom, body image, systemic effects and outlook for the future. In private health care systems, the results were sexual, social functions and body image. Women's quality of life was harmed by chemotherapy in both institutions.

Conclusion: The quality of life of women has been harmed as a result of the chemotherapy treatment in both institutions, but in different domains, indicating the type of nursing care that should be provided according to the characteristics of each group.

Keywords: Oncology nursing. Quality of life. Breast neoplasms.

\section{RESUMO}

Objetivo: 0 objetivo deste estudo foi investigar a qualidade de vida das mulheres com neoplasia mamária submetidas à quimioterapia nos convênios público e privado.

Método: Trata-se de estudo observacional, de coorte prospectivo, realizado com 64 mulheres portadoras de neoplasia mamária. Os dados foram coletados com a utilização dos instrumentos Quality of Life Questionnaire C30 e Breast Cancer Module BR23. Para análise dos dados, foram utilizados os testes estatísticos de Mann Whitney e Friedman, com valores estatisticamente significantes para $p<005$.

Resultados: Os resultados significantes no convênio público foram: função física, dor, imagem corporal, efeitos sistêmicos e perspectivas futuras. No convênio privado, foram: função sexual, social e imagem corporal.

Conclusão: A qualidade de vida das mulheres foi comprometida em decorrência do tratamento quimioterápico em ambas as instituiç̃ees, porém em domínios diferentes, o que subsidia um cuidado de enfermagem direcionado de acordo com as características de cada grupo.

Palavras-chave: Enfermagem oncológica. Qualidade de vida. Neoplasias da mama.

\section{RESUMEN}

Objetivo: Se objetivó investigar la calidad de vida de las mujeres con neoplasia mamaria sometidas a quimioterapia, en el seguro médico público y privado.

Método: Se trata de un estudio observacional, de cohorte, prospectivo, realizado con 64 mujeres con neoplasia mamaria. Los datos fueron recolectados mediante dos instrumentos Quality of Life Questionnaire C30 y Breast Cancer Module BR23. Para el análisis los datos se utilizaron pruebas estadísticas de Mann Whitney y Friedman, con valores estadísticamente significativas para $p<005$.

Resultados: Fueron verificadas diferencias estadísticamente significativas en el seguro médico público: la función física, síntoma dolor, la imagen corporal, los efectos sistémicos en las perspectivas de futuro, en el seguro médico privado fueron la función sexual, la imagen social y el cuerpo.

Conclusión: La calidad de vida de las mujeres se ha visto comprometida como consecuencia de la quimioterapia en ambas instituciones, pero en diferentes dominios que subsidia la atención de enfermería dirigida según las características de cada grupo.

Palabras clave: Enfermería oncológica. Calidad de vida. Neoplasias de la mama. 


\section{DINTRODUCTION}

Most women fear breast cancer. The disease is usually associated to physical mutilation, changes in style and quality of life (QL). Despite the technological advances in health regarding its treatment and the massive information disseminated by the media, the breast cancer rates are high, most probably because the disease is still diagnosed at advanced stages ${ }^{(1-2)}$.

In Brazil, the concern with this situation resulted in the Política Nacional de Atenção Oncológica ${ }^{(3)}$ (National Policy of Oncology (are) that emphasizes the importance of early detection and diagnosis, to provide women with better therapeutic results, prognosis and living conditions. Currently, the access to information differs depending on the characteristics of the population, impacting the time of diagnosis, the beginning of treatment and the quality of life of these women.

Therefore, an important landmark was the promulgation of Ordinance GM/MS no 2.439 whose primary goals were the promotion of quality of life and health in the society, ${ }^{(3)}$, and of Law no 2.732/2013 that provides for the beginning of treatment of patients diagnosed with cancer by the SUS (Unified Health System) within 60 days after the diagnosis ${ }^{(4)}$, to obtain better prognosis and quality of life.

In private health care centers, access to information and health care services is faster, which favors early diagnosis and treatment, However, the differences between public and private health centers may affect the quality of life of patients., The characteristics of the health providing system must be considered for the identification of the affected domains and the guarantee of assistance to these women in every stage of the treatment. Thus, the institutions must be prepared to support all the dimensions of the cancer treatment to improve the quality of life of the patients.

QL (quality of life) is defined by the World Health Organization as "an individual's perception of their position in life in the context of the culture and value system in which they live and in relation to their goals, expectations, standards and concerns" ${ }^{\prime \prime(5)}$. There is considerable agreement among researchers on the QL construct. Since, there is not yet consensus in this regard, it is remarkable that they focused on the patient's perception of the disease, treatment and its effects, reflecting knowledge, experiences, individual and collective values that concern different times and places in history ${ }^{(6-7)}$.

Breast cancer may cause different negative emotions in women, which can be strongly related to changes in their quality of life. These emotions include fear of diagnosis, fear of a possible surgery, uncertainty about the success of the treatment and the side effects of treatment, fear of pain and facing the possibility of impending death ${ }^{(8)}$.

Oncology Nursing integrates this concept because of the importance of its actions during the different stages of care to women with breast cancer, regarding prevention or early detection, diagnosis, treatment, guidance, palliative care and post-discharge follow-up. Thus, the investigation of $\mathrm{QL}$ in women suffering from breast cancer is based on the need to identify the affected domains, contemplating the physical, emotional, social and cognitive functions ${ }^{(9)}$.

Through the knowledge and monitoring of the symptoms of the disease and is side effects, important aspects that influence the QL of women with breast cancer can be assessed, allowing the evaluation of the treatment and its impact, as well as the planning of nursing interventions for the rehabilitation of these patients and the guarantee of better QL conditions ${ }^{(10)}$.

Based on the aforementioned, the hypothesis of this study was that the impact generated by anticancer treatment affects the QL of women with breast cancer, regardless of the type of health institution. Therefore, the present study aimed to investigate the QL of women with breast cancer who underwent chemotherapy in public and private health systems, identify and compare the main symptoms and domains affected between both institutions.

\section{METHODOLOGY}

Observational and prospective study conducted at the hematology and oncology unit of a public teaching hospital (referred to as IA for the purposes of the study) and in the chemotherapy unit of a private clinic (referred to as IB for the purposes of this study). The study was conducted between May 2012 and September 2013, with the inclusion of 64 women (32 IA and 32 IB) by convenience sampling. The inclusion criteria were: confirmed diagnosis of breast cancer, aged over 18 and beginning chemotherapy treatment within the specified period.

Data collection occurred in three stages of the treatment: the first up to 24 hours before the beginning of chemotherapy using three questionnaires: Questionnaire (1) socio-demographic and clinical data; Questionnaire (2) Quality of Life Questionnaire- C30 (QLQ-C30) developed by the European Organization for Research and 
Treatment of Cancer (EORTC)(11), specifically for cancer patients, translated into Portuguese, validated in Bra$\mathrm{Zil}^{(12)}$, with 30 items divided into five functional scales (physical, cognitive, emotional, social and performance), three scales of symptoms (fatigue, nausea and pain), six individual items (dyspnea, insomnia, loss of appetite, diarrhea and financial difficulties) and two questions on the general health status; Questionnaire (3) QLQ-BR23, translated into Portuguese, validated in Brazil(12), specifically targeted to QL in breast cancer, composed of 23 questions related to the side effects of chemotherapy, symptoms related to the arm and breast, body image and sexual function.

The second data collection occurred approximately 45 days after the beginning of chemotherapy, and the third one approximately 90 days after the beginning of the first collection and a 5-day margin (in both collections), using only the questionnaires QLQ-C30 and QLQ-BR23.

Socio-demographic data were analyzed by absolute and relative frequency. Data obtained from QLQ-C30 and BR23 was grouped in the respective scales and expressed in 0-100 scores. For the functional scales and general health status, a higher score represents a higher level of functionality and a better general health status. For the scales of symptoms, a higher score represents a greater number of symptoms. Non-parametric Mann Whitney test was used to compare data between the institutions. For comparison of the stages, non-parametric Friedman test was used. A significance level of $5 \%$ was considered, and values of $p<0.05$ were considered statistically significant.

Regarding ethical aspects, both questionnaires were authorized following registration of the project at the EORTC. The research was approved by the Research Ethics Committee of Hospital de Clínicas, UFPR, under no 5301, on March 12, 2012.

\section{QRESULTS}

Regarding the socio-demographic data (Table 1), the average age of 55 years was observed for IA, and of 44.9 years for IB. As to family income, IA showed an average of 3.9 minimum wages and IB an average of 13.8 minimum wages.

Regarding clinical data, it was found that $71 \%(n=23)$ of the women under treatment at IA reported having a comorbidity, with emphasis to high blood pressure or systemic arterial hypertension (SAH), diabetes, hypothyroidism and hypercholesterolemia. In IB there was a lower percentage of patients, $28.1 \%(n=9)$, with prevalence of SAH and hypothyroidism. Of the 23 patients that reported having $\mathrm{SH}, 69.5 \%(n=16)$ were in $\mathrm{IA}$ and $55.5 \%$ $(n=9)$ in IB.

Regarding life habits, the responses of the patients in both institutions were similar. In the IA 56.2\% $(n=18)$ said they did not smoke, $18.7 \%(n=6)$ said they quit smoking and $25 \%(n=8)$ said they were smokers. In the IB, $75.1 \%$ ( $n=24)$ said they did not smoke, 9.3\% ( $n=3)$ quit smoking and $15.6 \%(n=5)$ were smokers. Regarding alcohol consumption, in IA, 71.8\% ( $n=23)$ said they did not drink alcohol, 28.1\% (n=9) drank moderate amounts of alcohol and none reported heavy drinking. In IB 87.5\% ( $n=28)$ did not drink alcohol 9.3\% $(n=3)$ drank moderate amounts of alcohol and 3.2\% $(n=1)$ were heavy drinkers.

Regarding physical activities, in IA 59.3\% ( $n=19)$ did not practice any physical activity, $21.8 \%(n=7)$ practiced physical activity sporadically and $18.7 \%(n=6)$ regularly. In IB, 56\% ( $n=18)$ did not practice any physical activity, 21\% $(n=7)$ practiced physical activity sporadically and $21 \%$ $(n=7)$ regularly.

Regarding the time elapsed from the date of diagnosis to the beginning of treatment, in IA, it ranged from 1 to 24 months, with a mean of 5 months, and in IB the time was 1-7 months, with a mean of 2.6 months.

Regarding the results related to the questionnaires QLQ-C30 collected in the first stage (Table 2), statistically significant differences were observed between the groups for Physical Function ( $p=0.017)$ and Pain $(p=0.005)$ in the beginning of the treatment. No statistically significant differences between the institutions were found in the second stage. In the third stage there was a statistically significant difference for the item Social Function ( $p=0.049$ ).

Regarding the data of the BR23 tool in the first stage (Table 3), we detected statistically significant differences between the groups in the domains Body Image $(p=0.016)$, Sexual Function $(p=0.027)$ and Systemic Effects $(p=0.0001)$.

We observed statistically significant differences in the domains Sexual Function ( $p=0.002$ ), Outlook for the future $(p=0.049)$ and Systemic Effects $(p=0.035)$ in the findings of the second stage of questionnaire BR23 (Table 4).

In the third stage of the instrument there were no statistically significant differences between the items in the two institutions. The item Sexual Pleasure obtained the lowest response rate, and this was expected because it is related to women's intimacy. According to the Scoring Manual da EORTC(9), the variation in the number of responses in the BR23 is expected because the domains Sexual Pleasure and Hair Loss are not applicable when the responses related to these domains are negative. 
Garcia SN, Jacowski M, Castro GC, Galdino C, Guimarães PRB, Kalinke LP

Table 1 - Socio-demographic data $(n=64)$. Curitiba, PR, 2013

\begin{tabular}{|c|c|c|c|c|}
\hline Variables & IA & IA & I B & IB \\
\hline \multirow[t]{2}{*}{ Age (years) } & 55 & $30 \leftrightarrow 77$ & 44.9 & $24 \leftrightarrow 69$ \\
\hline & $n=32$ & $\%$ & $n=32$ & $\%$ \\
\hline \multicolumn{5}{|l|}{ Marital status } \\
\hline Single & 3 & 9.3 & 3 & 9.3 \\
\hline Married or living with a partner & 24 & 75 & 24 & 75 \\
\hline Separated or divorced & 3 & 9.3 & 4 & 12.5 \\
\hline Widow & 2 & 6.4 & 1 & 3.2 \\
\hline \multicolumn{5}{|l|}{ Number of children } \\
\hline None & 1 & 3.2 & 2 & 6.4 \\
\hline 1 to 3 children & 22 & 68.7 & 28 & 87.5 \\
\hline 3 or more & 9 & 28.1 & 2 & 6.4 \\
\hline \multicolumn{5}{|l|}{ Education } \\
\hline Illiterate & 1 & 3.2 & 0 & 0 \\
\hline Up to 9 years of education & 9 & 28.1 & 2 & 6.4 \\
\hline 9 to 12 years of education & 13 & 40 & 12 & 37.5 \\
\hline More than 12 years of education & 9 & 28.1 & 18 & 56.2 \\
\hline \multicolumn{5}{|l|}{ Occupation } \\
\hline Economically active & 10 & 31.2 & 19 & 59.6 \\
\hline Retired & 9 & 28.1 & 1 & 3.1 \\
\hline Housewife & 8 & 25 & 7 & 21.8 \\
\hline Unemployed & 5 & 15.6 & 5 & 15.6 \\
\hline Family income & $3.9^{*}$ & - & $13.8^{*}$ & - \\
\hline Per capita income & $1^{*}$ & - & $4.4^{*}$ & - \\
\hline
\end{tabular}

Source: Research data, 2013.

*Value in minimum wages

\section{DISCUSSION}

Knowledge of the therapeutic itinerary of women with breast cancer contributes to the planning of nursing care and actions in health care aimed to promote QL. Therefore, knowing the socioeconomic and clinical profile of the patient, as well as the physical, social, emotional and cognitive functions, contributes to reduce the disparities in health, according to demographic, epidemiological and socioeconomic differences.

The age range of women who underwent chemotherapy in the IA was consistent with the national average (52 years $)^{(13)}$. On the other hand, the women treated in the IB were on average under the age group of highest incidence of breast cancer in our country. This difference can be related to the fact that younger women, in reproductive age, are more likely to have their breasts examined in medical consultations. Also, the private health system facilitates the access to early diagnosis ${ }^{(14)}$.

Concerning education, it can be seen that the economically active women in the sample tended to have a higher educational level. This situation was observed in IB. The relationship between educational level and breast cancer indicates that individuals with lower education were less likely to adopt prevention measures against breast cancer. Thus, a higher level of education provides better understanding and consequently increased participation in screening methods ${ }^{(15)}$. 
Table 2 - Data from QLQ-C30 applied in the first stage ( $n=64)$. Curitiba - PR 2013

\begin{tabular}{|c|c|c|c|c|}
\hline \multirow[b]{2}{*}{ Scores } & \multicolumn{2}{|c|}{ Sum of ranks } & \multirow[b]{2}{*}{$\mathbf{U}$} & \multirow[b]{2}{*}{ p-value } \\
\hline & $\underset{n=32}{\mathrm{IA}}$ & $\begin{array}{c}\text { IB } \\
n=32\end{array}$ & & \\
\hline Global quality of life & 999 & 1081 & 471 & 0.588978 \\
\hline Physical function & 864 & 1216 & 336 & $0.017721^{*}$ \\
\hline Personal performance & 894.5 & 1185.5 & 366.5 & 0.050283 \\
\hline Emotional function & 1067.5 & 1012.5 & 484.5 & 0.713808 \\
\hline Cognitive function & 991.5 & 1088.5 & 463.5 & 0.517476 \\
\hline Social function & 1024 & 1056 & 496 & 0.836270 \\
\hline Fatigue & 1085 & 995 & 467 & 0.552668 \\
\hline Nausea / Vomiting & 1140 & 940 & 412 & 0.182825 \\
\hline Pain & 1246.5 & 833.5 & 305.5 & $0.005021^{*}$ \\
\hline Dyspnea & 1140 & 940 & 412 & 0.182825 \\
\hline Insomnia & 979.5 & 1100.5 & 451.5 & 0.419190 \\
\hline Loss of appetite & 1045 & 1035 & 507 & 0.952160 \\
\hline Constipation & 1090 & 990 & 462 & 0.508861 \\
\hline Diarrhea & 1184 & 896 & 368 & 0.053589 \\
\hline Financial difficulties & 1088 & 992 & 464 & 0.526166 \\
\hline
\end{tabular}

Source: Research data, 2013.

*Statistically significant

As for occupation, it was possible to observe that in IB $59 \%$ of the women declared themselves as economically active, almost twice the result in IA, a factor that also reflects in the family average pay, which is three times higher in the IB. Some authors stress the importance of the active participation of women in the labor market or in the family environment. Thus, taking a sick-leave for treatment combined to the emotional trauma of being diagnosed with breast cancer and the fear of treatment can have a very negative impact on a woman's life ${ }^{(9)}$, contributing to decrease in QL.

The QL of women with breast cancer can also be affected by the presence of previous pathologies and by some anticancer therapies that can favor the onset or worsen some type of comorbidity, such as cardiovascular diseases, with a negative impact on the prognosis ${ }^{(16)}$. In the present study, $50 \%$ of the women had some comorbidity, and SAH was the most prevalent.

The fact that most women did not report being alcoholics or smokers, a factor that predisposes to cancer, was also remarkable. Nevertheless, regarding physical activity, approximately half of both groups of women said they did not practice any physical activity. It is known that regular physical activity is a protective factor against the development of breast cancer ${ }^{(16)}$.

One key aspect of the QL of patients with breast cancer is the time of diagnosis, and the two institutions differed significantly in this regard. The beginning of treatment in IA was almost twice slower than in IB. In an attempt to this problem in Brazil, Law 12.732 came into force in 2013, providing for the beginning of treatment of patients diagnosed with cancer by the SUS (Unified Health System) within 60 days after the diagnosis ${ }^{(4)}$. Regardless of the factors responsible for the delayed treatment after diagnosis, some studies observed that delayed diagnoses and treatment of breast cancer were associated to the worst prognosis ${ }^{(17)}$, and this will cause women to be more likely to require a more aggressive treatment, with greater impact on the QL.

Regarding the data related to questionnaires QLQ-C30 and BR23, in the item general health status, in both institutions, the score was not low, that is, both institutions reported a "satisfactory level" in health status. However, regarding the affected domains, in the first stage of the study, a deficit was observed in Physical Function and the symptom Pain was more frequent in $\mathrm{IA}$, indicating a possible relationship 
Garcia SN, Jacowski M, Castro GC, Galdino C, Guimarães PRB, Kalinke LP

Table 3 - Data from questionnaire BR23 applied in the first stage $(n=64)$. Curitiba - PR 2013

\begin{tabular}{|c|c|c|c|c|c|c|}
\hline \multirow{2}{*}{ Scores } & \multicolumn{2}{|c|}{ Sum of ranks } & \multirow{2}{*}{$\mathbf{U}$} & \multicolumn{2}{|c|}{$N$} & \multirow{2}{*}{$p$-value } \\
\hline & IA & IB & & IA & IB & \\
\hline Body Image & 850 & 1166 & 322 & 32 & 31 & $0.016326^{*}$ \\
\hline Sexual Function & 1184 & 832 & 336 & 32 & 31 & $0.027610^{*}$ \\
\hline Sexual Pleasure & 367 & 413 & 113 & 15 & 24 & 0.054162 \\
\hline Outlook for the future & 936 & 1144 & 408 & 32 & 32 & 0.165703 \\
\hline Systemic Effects & 1313.5 & 766.5 & 238.5 & 32 & 32 & $0.000159^{*}$ \\
\hline Breast Symptoms & 1185 & 895 & 367 & 32 & 32 & 0.051914 \\
\hline Arm Symptoms & 1009 & 1007 & 481 & 32 & 31 & 0.843099 \\
\hline Hair loss & 156.5 & 143.5 & 38.5 & 10 & 14 & 0.064329 \\
\hline
\end{tabular}

Source: Research data, 2013.

* Statistically significant

Table 4 - Data from questionnaire BR23 applied in the second stage of the study ( $n=64)$. Curitiba - PR 2013

\begin{tabular}{|c|c|c|c|c|c|c|}
\hline \multirow{2}{*}{ Scores } & \multicolumn{2}{|c|}{ Sum of ranks } & \multirow{2}{*}{$\mathbf{U}$} & \multicolumn{2}{|c|}{$N$} & \multirow{2}{*}{$p$-value } \\
\hline & IA & IB & & IA & IB & \\
\hline Body Image & 924 & 1092 & 428 & 31 & 32 & 0.355903 \\
\hline Sexual Function & 1231 & 722 & 226 & 31 & 31 & $0.000240^{*}$ \\
\hline Sexual Pleasure & 228 & 300 & 69 & 11 & 21 & 0.067453 \\
\hline Outlook for the future & 847 & 1169 & 351 & 31 & 32 & $0.046449^{*}$ \\
\hline Systemic Effects & 1145 & 871 & 343 & 31 & 32 & $0.035387^{*}$ \\
\hline Breast Symptoms & 994 & 1022 & 494 & 31 & 32 & 0.983665 \\
\hline Arm Symptoms & 955.5 & 1060.5 & 459.5 & 31 & 32 & 0.618138 \\
\hline Hair loss & 841 & 812 & 406 & 29 & 28 & 1.000000 \\
\hline
\end{tabular}

Source: Research data, 2013

* Statistically significant

between the time of diagnosis, beginning of treatment and staging of cancer. Cancer pain affects around 50\% of the patients at all stages of the disease in $60 \%$ to $90 \%$ of advanced cancers ${ }^{(18)}$.

Systemic Effects (fatigue, loss of interest in previously pleasurable activities, dyspnea, loss of muscle strength, altered taste, irritability, loss of concentration, gastrointestinal disorders and reduced sexual desire) are more common from the second chemotherapy session (7). However, they were detected in the patients of group $I A$, in the first and second stages, possibly related to the late diagnosis, which may lead to AM more aggressive treatment and to the difficulty in obtaining drugs to minimize these symptoms.
As a result of the symptoms, the treatment for breast cancer causes changes in the independence and autonomy of women, generating psychosocial problems. This fact aggravates the functional condition, which involves dependence and loss of identity, besides generating anxiety, fears and impairing emotional function and $\mathrm{QL}^{(1)}$.

The possibility of partial or total breast amputation, in addition to increasing pain symptoms, has a direct impact on body image because of its association with femininity, sensuality, sexuality and maternity ${ }^{(2)}$. Just like surgical intervention, systemic treatments (chemotherapy and/or radiotherapy) also cause side effects that can impact body image due to hair loss, skin burns, decreased libido and 
fertility, as they interfere with the production of sex hormones, leading to vaginal dryness and early menopause in the case of younger patients ${ }^{(10)}$.

Therefore, body image is understood as a key feature of sexual function, since the maintenance and acceptance of femininity, even after the clinical interventions of the treatment, are essential to the sexual satisfaction of the woman and her partner ${ }^{(19)}$.

Body image goes beyond visual aspects and comprises the affective, social and physiological experiences that influence the way in which the woman perceives herself. In this regard, body image was found to be more affected by the treatment for the women of group IA, which is correlated to the factors that limit these women in their sociability and result in the low levels of resilience to cope with the disease. ${ }^{(17)}$.

Although Body Image is better rated in group IB, the score for Sexual Function was lower than that of IA, which implies a contradiction with the studies that relate Body Image and Sexual Function. Quantitative studies may cover the entire understanding of Body Image, because it is a subjective perception of one's own body, and that differs for each woman who feels physically invaded and exposed to the changes caused by the treatment ${ }^{(1)}$.

\section{- CONCLUSION}

The present study investigated the possible impacts of breast cancer and anticancer treatment cause to the QL of women in public and private health institutions. These impacts were perceived in physical function, sexual function, pain, body image, systemic effects and outlook for the future that affected the QL of the women.

However, it can be inferred that the QL of the women was affected by chemotherapy regardless of the type of institution. Therefore, the outcomes point to the need to know the group of origin of each patient, since this information will be useful for the development of strategies aimed to strengthen specific health measures, resulting in a more targeted and efficient care, which will have a positive impact on the QL.

Women with breast cancer who undergo chemotherapy require whole assistance, and the nursing actions must seek the balance between the maintenance of physical, emotional and social functions of the patients, through the appropriate management of the physiological symptoms caused by chemotherapy drugs, focusing on the quality of life that should be ensured despite the adverse effects of the therapy.

\section{QREFERENCES}

1. Silva CB, Albuquerque V, Leite J. Qualidade de vida em pacientes portadoras de neoplasia mamária submetidas a tratamentos quimioterápicos. Rev Bras Cancerol. 2010;56(2):227-36.

2. Majewski JM, Lopes ADF, Davoglio T, Leite JCC. Qualidade de vida em mulheres submetidas à mastectomia comparada com aquelas que se submeteram à cirurgia conservadora: uma revisão de literatura. Cienc Saude Coletiva [Internet]. 2012 [citado 2013 abr. 25];17(3):707-16. Disponível em: http://www.scielo.br/ scielo.php?script=sci_arttext\&pid=S1413-81232012000300017.

3. Ministério da Saúde (BR). Portaria n. 2.439, de 8 de dezembro de 2005. Institui a Política Nacional de Atenção Oncológica: promoção, prevenção, diagnóstico, tratamento, reabilitação e cuidados paliativos, a ser implantada em todas as unidades federadas, respeitadas as competências das três esferas de gestão. Diário Oficial da União, Brasília (DF) 2005 dez. 09; 142(236 Seção 1):80-1.

4. Ministério da Saúde (BR). Lei n. 12.732, de 22 de novembro de 2012. Dispõe sobre o primeiro tratamento de paciente com neoplasia maligna comprovada e estabelece prazo para seu início. Diário Oficial da União, Brasília (DF) 2012 nov. 23;149(226 Seção 1):1.

5. World Health Organization (SW). WHOQ0L: measuring quality of life. Geneva; 1997.

6. Seixas RJ, Kessler A, Frison VB. Atividade física e qualidade de vida em pacientes oncológicos durante o período de tratamento quimioterápico. Rev Bras Cancerol [Internet]. 2010 [citado 2013 mar. 04];56(4):321-30. Disponível em: http:// www.inca.gov.br/rbc/n_56/v03/pdf/05_artigo_atividade_fisica_qualidade_vida_pacientes_on cologicos_durante_periodo_tratamento_quimioterapico.pdf.

7. Zandonai AP, Cardozo FMC, Nieto ING, Sawada NO. Qualidade de vida nos pacientes oncológicos: revisão integrativa da literatura latino-americana. Rev Eletr Enf [Internet]. 2010 [citado 2013 set. 06];12(3):554-61. Disponível em: http:// www.fen.ufg.br/revista/v12/n3/v12n3a20.htm.

8. Sales CACC, Paiva L, Scandiuzzi D, Anjos ACY. Qualidade de vida de mulheres tratadas de câncer de mama: funcionamento social. Rev Bras Cancerol [Internet]. 2011 [citado 2013 jul. 31]; 47(3):263-72. Disponível em: http://www.inca.gov. $\mathrm{br/rbc/n \_ 47/v03/english/article2.html.}$

9. Stumm EMF, Leite MTL, Maschio G. Vivências de uma equipe de enfermagem no cuidado a pacientes com câncer. Cogitare Enferm [Internet]. 2008 [citado 2013 set. 11];13(1):75-82. Disponível em: http://ojs.c3sl.ufpr.br/ojs/index.php/cogitare/article/view/11955/8436

10. Pelusi J. Sexuality and body image: research on breast cancer survivors documents altered body image and sexuality. Am J Nurs. 2006; 106(Suppl 3):32-8.

11. EORTC.org [Internet]. Brussels: The European Organisation for Research and Treatment of Cancer; c2011-2015 [atualizado 2014 fev. 04, citado 2014 fev. 04]. Disponível em: http://www.eortc.org.

12. Michels FAS, Latorre MRDO, Maciel MS. Validity, reliability and understanding of the EORTC-C30 and EORTC-BR23, quality of life questionnaires specific for breast cancer. Rev Bras Epidemiol. 2013;16(2):52-63.

13. Instituto Nacional do Câncer [Internet]. Rio de Janeiro: INCA; c1996-2015 [atualizado 2013; citado 2013 maio 05]. 0 que é o câncer; [aprox. 2 telas]. Disponível em: http://www1.inca.gov.br/conteudo_view.asp?id=322.

14. Rodrigues CS, Givisiez JHN. Estudo da acessibilidade ao serviço de saúde de pacientes com câncer de mama no município de campos dos Goytacazes. In: XVII Encontro Nacional de Estudos Populacionais; 2010 set. 20-24; Caxambu, Brasil. Disponível em: http://www.abep.nepo.unicamp.br/encontro2010/docs_pdf/ eixo_4/abep2010_2207.pdf. 
15. Fangel LMV, Panobianco MS, Kebbe LM, Almeida AM, Gozzo TO. Qualidade de vida e desempenho de atividades cotidianas após tratamento das neoplasias mamárias. Acta Paul Enferm [Internet]. 2013 [citado 2013 ago. 01];26(1):93100. Disponível em: http://www.scielo.br/scielo.php?script=sci_arttext\&pid $=$ S01031002013000100015\&lng=en\&nr $m=i s 0$.

16. Anjos JC, Alayala A, Hofelmann DA. Fatores associados do câncer de mama. Cad Saúde Colet [Internet]. 2012 [citado 2013 set. 28];20(3):341-50. Disponível em: http://www.iesc.ufrj.br/cadernos/images/csc/2012_3/artigos/ CSC_v20n3_341-350.pdf.
17. Silva PA, Riul SS. Câncer de mama: fatores de risco e detecção precoce. Rev Bras Enferm [Internet]. 2011 [citado 2013 set. 28];64(6):1016-21. Disponível em: http://www.scielo.br/pdf/reben/v64n6/v64n6a05.pdf.

18. Biasi PT, Zago VLP, Paini JFP, De Biasi LS. Manejo da dor no paciente oncológico pela equipe de enfermagem. Perspectiva [Internet]. 2011 [citado 2013 set. 29]; 35(129):157-66. Disponível em: http://www.uricer.edu.br/new/site/pdfs/ perspectiva/129_163.pdf.

19. Falk Dahl CA, Reinertsen KV, Nesvold IL, Fossa SD, Dahl AA. A study of body image in long-term breast cancer survivors. Cancer. 2010 Aug;116(15):3549-57.
Author's address:

Luciana Puchalski Kalinke

Curso de Enfermagem, Bloco Didático II, Campus Botâni-

co, Setor de Ciências da Saúde

Av. Lothário Meissner, 632, Jardim Botânico

80210-170 Curitiba - PR

E-mail: lucianakalinke@yahoo.com.br
Received: 17.03.2014

Approved: 01.06.2015 